\title{
Efficacy and safety of ultrasound (US)- guided radiofrequency ablation of benign thyroid nodules
}

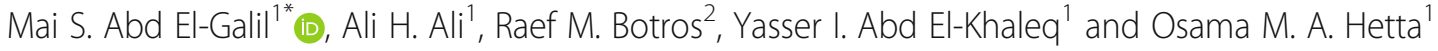

\begin{abstract}
Background: We evaluated 45 benign thyroid nodules of 40 patients treated with radiofrequency (RF) ablation and followed up for 6 months. The inclusion criteria included unilateral or bilateral thyroid nodules with compression symptoms or cosmetic problems, cytological confirmation of benignity without atypical cells, and patient refusal or unfit for surgery. There was no predilection for the size, number, ultrasound nature of the nodules, (solid, cystic, or complex). RF ablation was performed using Mygen (M-3004) RF generator from RF Medical Co., Ltd, South Korea. The volume of the nodules and clinical problems were evaluated before and after the procedure. Complications and factors related to volume reduction were evaluated. The purpose of the study is to evaluate the efficacy and safety of US-guided radiofrequency (RF) ablation in the treatment of benign thyroid nodules.

Results: The volume reduction ratio (\%) of the thyroid nodules was statistically significant. The mean VRR was 58.41 $\pm 15.27 \mathrm{SD}$ at 1 month, $73.26 \pm 11.22 \mathrm{SD}$ at 3 months, and $82.54 \pm 12.49 \mathrm{SD}$ at 6 months. $P$ value was $<0.001$. The radiofrequency ablation did not affect the normal thyroid function of the 38 patients who were euthyroid at the start of the study. Thyroid function normalized 1 month after ablation of the two autonomously functioning thyroid nodules. The compressive symptoms resolved in 22 patients (55\%) and improved in the rest of the 18 patients (45\%) with the median decreased from 8 (IQR 6-9), range 4-10 before treatment to 0 (IQR 0-1), range 0-3 after 6 months. Cosmetic problems improved in all 40 patients by $P$ value $<0.001$. The procedure had no sustained or lifethreatening complications.

Conclusions: RF ablation was effective in reducing the size of the benign thyroid nodules and in controlling nodule-related compressive symptoms as well as cosmetic problems. There were no major complications sustained and no life-threatening complications or sequelae happened. RF ablation can be used as an alternative non-surgical minimally invasive treatment for patients with benign thyroid nodules.
\end{abstract}

Keywords: Radiofrequency ablation, Benign thyroid nodules, Ultrasound, Autonomously functioning thyroid nodule, Fine needle aspiration biopsy

\section{Background}

Nodular thyroid disease is a very common finding in clinical practice [1]. The prevalence of the thyroid nodules is 20 to $76 \%$ [2]. Although most of thyroid nodules are benign and do not require treatment, some benign nodules may require treatment for

\footnotetext{
* Correspondence: maishaban73@gmail.com

${ }^{1}$ Radiodiagnosis Department, Ain Shams University Hospitals, Cairo, Egypt Full list of author information is available at the end of the article
}

associated compression symptoms and/or cosmetic problems [3]. Surgery and radioiodine therapy have been used for patients with symptomatic thyroid nodules, although both surgery and radioiodine therapy can cause complications, such as voice change or hypothyroidism [4]. Over the last two decades, non-surgical, minimally invasive, US-guided techniques have been proposed for the treatment of thyroid nodules [1]. Radiofrequency ablation (RFA) is a 


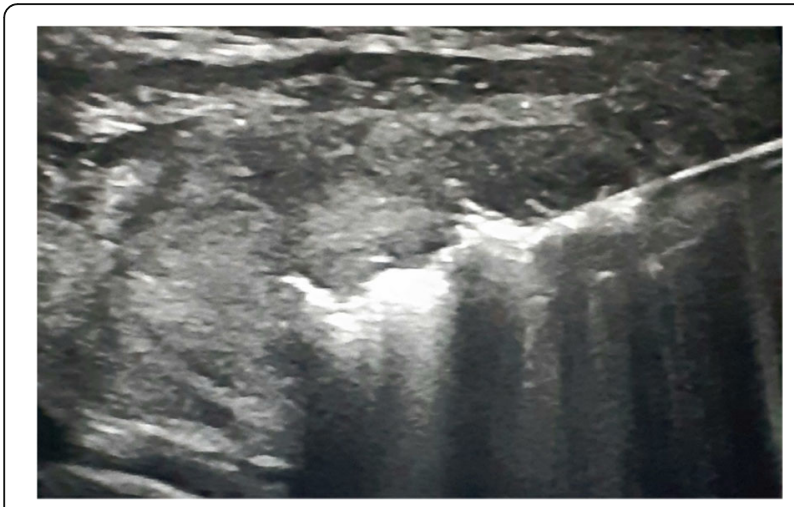

Fig. 1 US picture of the RF electrode passing through the thyroid nodule and a transient hyperechoic zone around its tip

new minimally invasive modality that serves as an alternative to surgery in patients with benign thyroid nodules [5]. Benign thyroid nodules and AFTN could be treated by RF ablation [6]. RFA has been shown to relieve compressive symptoms and cosmetic problems caused by benign thyroid nodule $s$ [6]. The purpose of this study is to evaluate the efficacy and safety of US-guided radiofrequency (RF) ablation for treatment of benign thyroid nodules as well as preservation of the normal thyroid function.

\section{Methods \\ Patients}

Forty patients, 28 (70.0\%) females and $12(30.0 \%)$ males, with a mean age $\pm \mathrm{SD}=47.28 \pm 13.79$ years, age range 21-80 years, received RF ablation for benign thyroid nodules in our institute and other different private hospitals. An informed consent was obtained from all patients before each procedure. Among them, patients were enrolled as they fulfilled the following criteria: reported compressive symptoms and/or cosmetic problems, cytologically confirmed benign thyroid nodule on tru-cut biopsy or two separate US-guided FNAB or one FNAB with US imaging finding without suspicious malignant features $[7,8]$, baseline serum thyroid profile either normal level or high in case of AFTN, and refusal of or unfit for surgery.

\section{Preparation and participation}

Before RF ablation, clinical evaluation for compression symptoms and cosmetic problems, US imaging (volume of the thyroid nodule and the composition of the nodule either solid, complex, or cystic) [9], and laboratory data

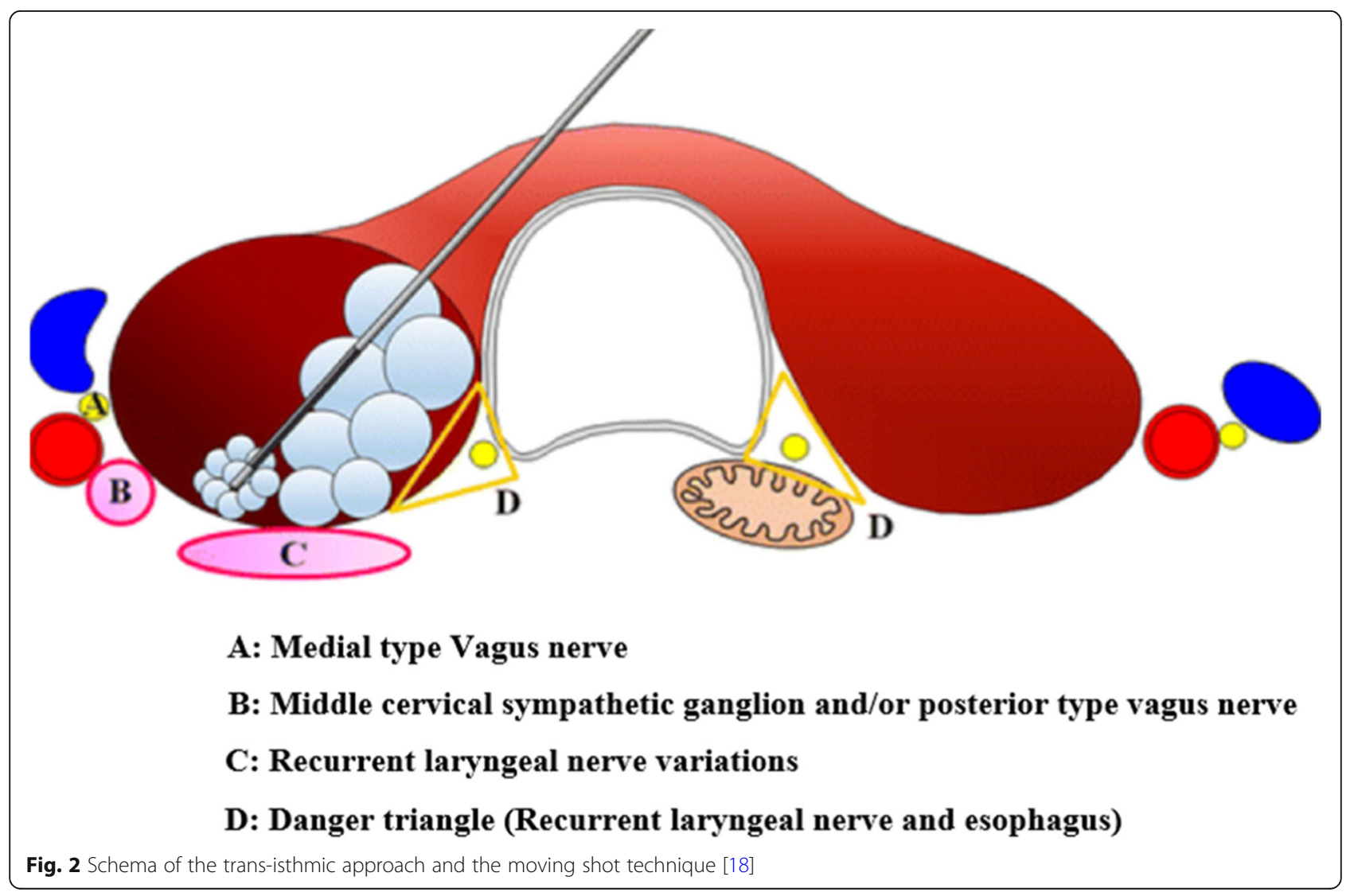


Table 1 Main characteristics and baseline clinical data of the 40 patients

\begin{tabular}{lll}
\hline & & Total no. of the patients $=\mathbf{4 0}$ \\
\hline Gender & Females & $28(70.0 \%)$ \\
& Males & $12(30.0 \%)$ \\
Age (years) & Mean \pm SD & $47.28 \pm 13.79$ \\
& Range & $21-80$ \\
Compressive symptoms scoring & Median (IQR) & $8(6-9)$ \\
$(0-10)$ & Range & $4-10$ \\
Cosmetic problem scoring & Median (IQR) & $4(3-4)$ \\
$(1-4)$ & Range & $2-4$ \\
Thyroid profile & Euthyroidism & $38(95.0 \%)$ \\
& Hyperthyroidism & $2(5.0 \%)$ \\
Recurrent state & Yes & $8(20.0 \%)$ \\
Number of nodules & No & $32(80.0 \%)$ \\
Type of anesthesia & Single nodule & $35(87.5 \%)$ \\
& Two dominant nodules & $5(12.5 \%)$
\end{tabular}

(thyroid hormone level) were obtained for all patients [10]. One tru-cut biopsy or two separate FNAB were performed using a linear probe $(10 \mathrm{MHz})$. The three diameters of each nodule (i.e., the largest diameter and two other perpendicular diameters) were measured by ultrasound and the nodule volumes were calculated using the following equation rabc/6 (where (a) is the largest diameter, (b) and (c) are the other two perpendicular diameters). In case of multiple thyroid nodules in each lobe, the single dominant nodule was measured and treated. At the time of their enrollment, patient rated their symptoms on a 10-point visual analog scale (range 0-10) [11-13] and cosmetic grading score was assessed: (1) no palpable mass, (2) no cosmetic problem but a palpable mass, (3) a cosmetic problem on swallowing only, and (4) a readily detected cosmetic problem
[11-13]. The baseline laboratory data included serum free T3 and T4 thyroid hormone level as well as TSH.

\section{Procedure}

RF ablation was performed on an outpatient basis. All patients were given a single dose of an intravenous antibiotic (sulbactam/ampicillin) and anti-edematous (hydrocortisone sodium succinate) drugs just before the procedure. We used Mygen (M-3004) RF generator from RF Medical Co., Ltd, South Korea, with a modified straight internally cooled (18 gauge, $7 \mathrm{~cm}$ in length) electrode with an active tip 5, 7, and $10 \mathrm{~mm}$ according to the size of the nodule $(13,14)$. "We used electrodes with an active tip $5 \mathrm{~mm}$ for the nodules less than $50 \mathrm{ml}$ in volume, $7 \mathrm{~mm}$ for the nodules were $50-100 \mathrm{ml}$ in volume and $10 \mathrm{~mm}$ for the larger nodules than $100 \mathrm{ml}$ volume".

Table 2 Main characteristics of the 45 thyroid nodules of the 40 patients

\begin{tabular}{|c|c|c|}
\hline & & Total no. of the nodules $=45$ \\
\hline \multirow[t]{2}{*}{ Volume of the nodule (ml) } & Median (IQR) & $15(8.5-39.5)$ \\
\hline & Range & $0.5-245$ \\
\hline \multirow[t]{3}{*}{ U/S picture } & Solid & $27(60.0 \%)$ \\
\hline & Complex & $16(35.6 \%)$ \\
\hline & Cystic & $2(4.4 \%)$ \\
\hline \multirow[t]{2}{*}{ Retrosternal extension } & Yes & $7(15.6 \%)$ \\
\hline & No & $38(84.4 \%)$ \\
\hline \multirow[t]{2}{*}{ Function of the thyroid nodules } & Nonfunctioning thyroid nodules & $43(95.6 \%)$ \\
\hline & Autonomous functioning thyroid nodules (AFTN) & $2(4.4 \%)$ \\
\hline
\end{tabular}




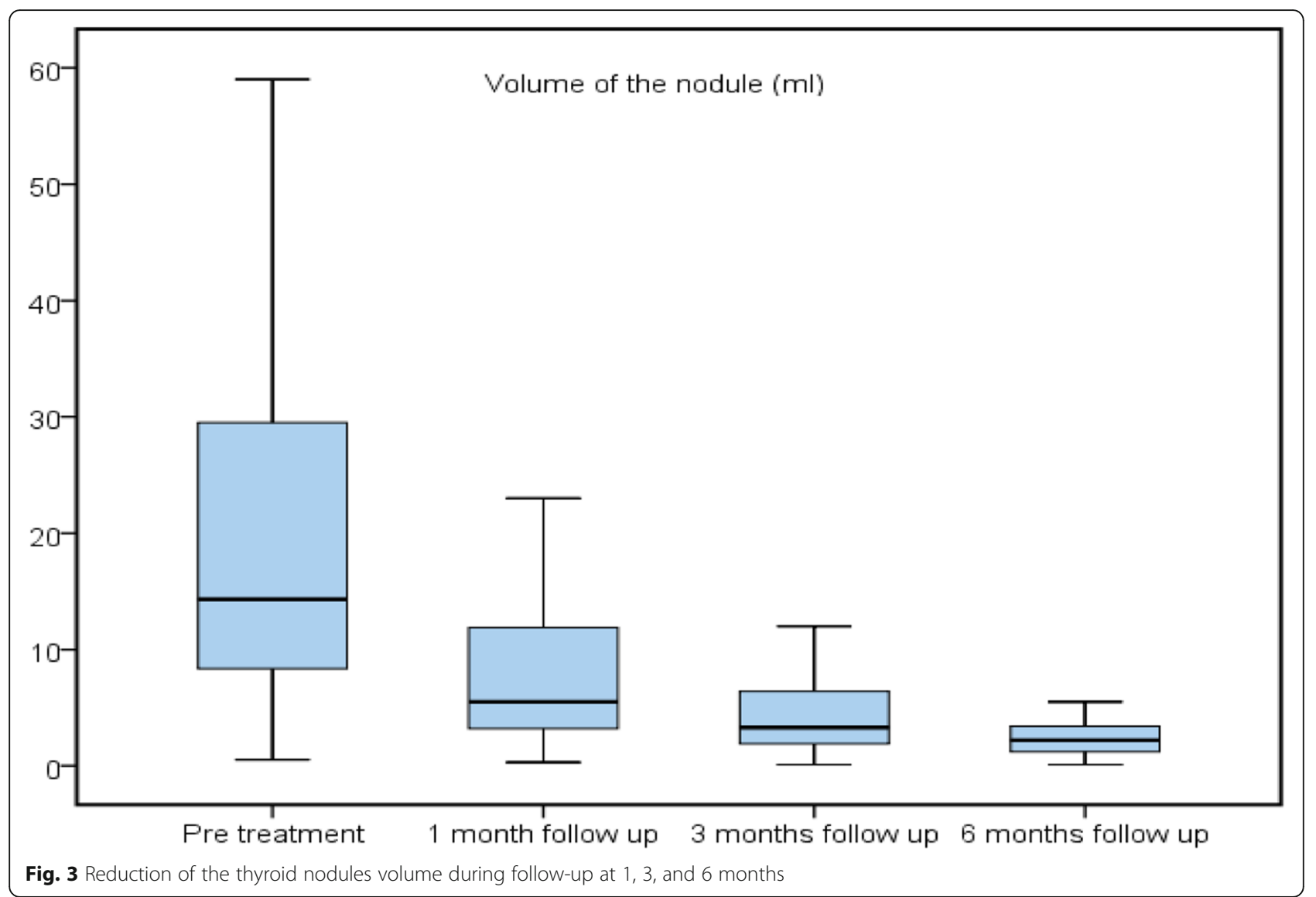

Six patients were treated under local anesthesia with $2 \%$ lidocaine at the puncture site. The rest of the 34 patients were treated under conscious sedation (Intravenous fentanyl with midazolam) as well as the local anesthesia. Cystic nodules were aspirated first before the ablation. Under US guidance, we performed hydro-dissection for all patients with $5 \%$ dextrose, either under the skin (to prevent skin burns) or to distance other critical structures near the ablation zone. Dextrose was re-administered regularly as it was seen to be re-absorbed under ultrasound [14]. During the procedure, we pay great attention to the preservation of surrounding important structures to prevent significant complication such as recurrent laryngeal nerve injury which is located in the trachea-esophageal groove. RF ablation was done using trans-isthmic approach and moving shot technique [1517]. Ablation began with $30 \mathrm{~W}$ power which was reduced if the patient did not tolerate the pain. If the formation of a transient hyperechoic zone at the electrode tip did not appear within $10 \mathrm{~s}$, power was increased in $10 \mathrm{~W}$ gradually up to $100 \mathrm{~W}$. When a transient hyperechoic zone expanded around the electrode tip (Fig. 1), the electrode was moved to an untreated area. This technique was named the "moving-shot technique" as shown in Fig. 2. Before ablation, we divide the nodule "the periphery of the nodule as well as the portion of the nodule adjacent to the critical neck structures" into units. The nodule was then treated unit by unit using the moving shot technique $[19,20]$. During the ablation both thighs were checked frequently to prevent skin burn. The ablation time and power ranged from 5 to 30 min (mean $14 \mathrm{~min}$ ) and 50-100 W respectively. Ablation was terminated when all units of the nodule had changed to transient hyper echoic zones [21]. Ice packs were applied during and after the ablation to prevent skin burns at the ablation probe puncture site. All patients except for the complicated ones were discharged

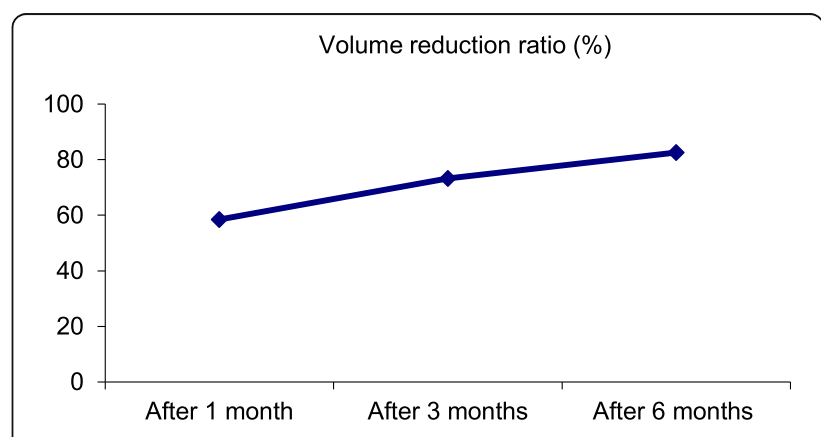

Fig. 4 Volume reduction ratio changes during the follow-up 


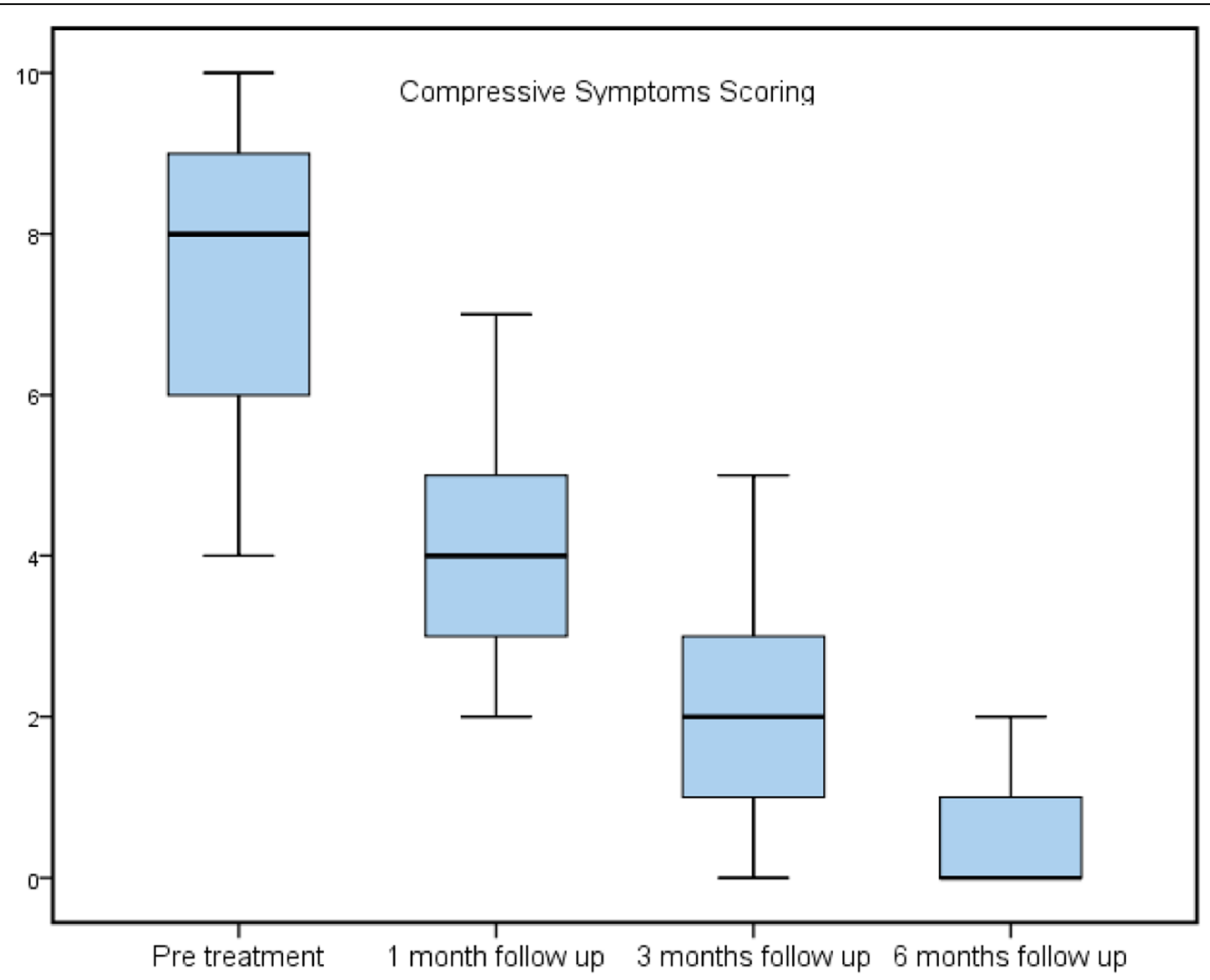

Fig. 5 Decreasing of the compressive symptoms scoring during follow-up

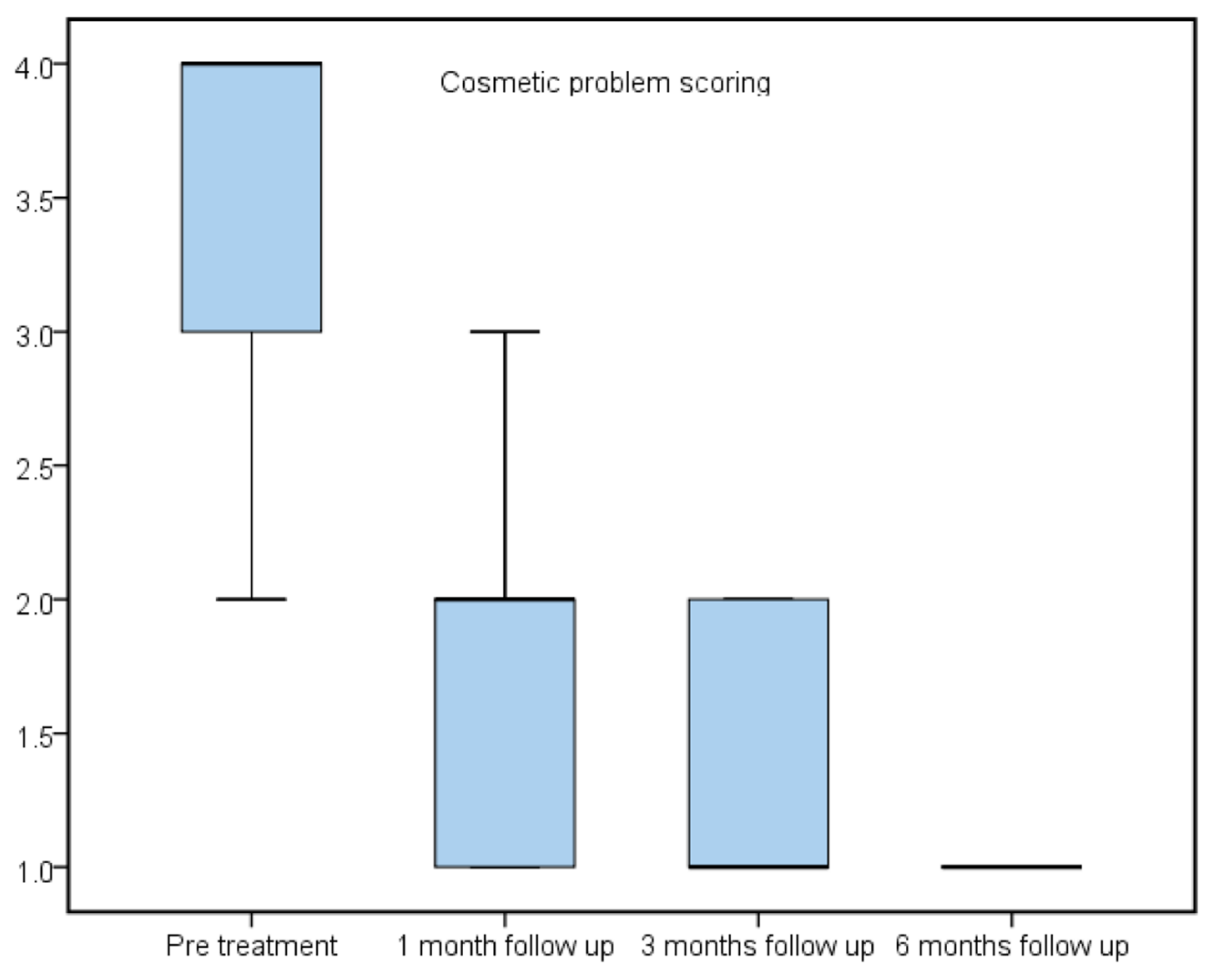

Fig. 6 Decreasing of the cosmetic problem scoring at 1, 3, and 6 months 
Table 3 Summary of the follow-up of the thyroid nodule volume, patients' symptoms, and the thyroid hormone level

\begin{tabular}{|c|c|c|c|c|c|c|c|c|}
\hline & & Pretreatment & $\begin{array}{l}1 \text { month follow- } \\
\text { up }\end{array}$ & $\begin{array}{l}3 \text { months' } \\
\text { follow-up }\end{array}$ & $\begin{array}{l}6 \text { months' } \\
\text { follow-up }\end{array}$ & $\begin{array}{l}\text { Test } \\
\text { value }\end{array}$ & $\begin{array}{l}P \\
\text { value }\end{array}$ & Sig. \\
\hline \multirow[t]{2}{*}{ Thyroid profile } & Euthyroidism & 38 (95.0\%) & $40(100.0 \%)$ & $40(100.0 \%)$ & $40(100.0 \%)$ & $6.076^{\mathrm{a}}$ & 0.108 & NS \\
\hline & Hyperthyroidism & $2(5.0 \%)$ & $0(0 \%)$ & $0(0 \%)$ & $0(0 \%)$ & & & \\
\hline \multirow{2}{*}{$\begin{array}{l}\text { Compressive symptoms } \\
\text { scoring } \\
(0-10)\end{array}$} & Median (IQR) & $8(6-9)$ & $4(3-5)$ & $2(1-3)$ & $0(0-1)$ & $105.952^{\mathrm{b}}$ & 0.000 & HS \\
\hline & Range & $4-10$ & $2-7$ & $0-5$ & $0-3$ & & & \\
\hline \multirow{2}{*}{$\begin{array}{l}\text { Cosmetic scoring } \\
(1-4)\end{array}$} & Median (IQR) & $4(3-4)$ & $2(1.5-2)$ & $1(1-2)$ & $1(1-1)$ & $81.506^{b}$ & 0.000 & HS \\
\hline & Range & $2-4$ & $1-4$ & $1-4$ & $1-4$ & & & \\
\hline \multirow[t]{2}{*}{ Volume of the nodule } & Median (IQR) & $15(8.5-39.5)$ & $5.5(3.2-12)$ & $3.3(1.9-6.8)$ & $2.2(1.2-3.5)$ & $104.985^{b}$ & 0.000 & HS \\
\hline & Range & $0.5-245$ & $0.3-118$ & $0.1-96$ & $0.1-30$ & & & \\
\hline \multirow[t]{2}{*}{ Volume reduction ratio (\%) } & Mean \pm SD & - & $58.41 \pm 15.27$ & $73.26 \pm 11.22$ & $82.54 \pm 12.49$ & 92.900 & 0.000 & HS \\
\hline & Range & - & $29.52-96.23$ & $40-94.14$ & $36-98.28$ & & & \\
\hline
\end{tabular}

$P$ value $>0.05$, non-significant; $P$ value $<0.05$, significant; $P$ value $<0.01$, highly significant

${ }^{\text {a }}$ Chi-square test

${ }^{\mathrm{b}}$ Friedman test

within $30 \mathrm{~min}$ after the procedure including patients who were sedated but after complete recovery from the sedation and advised to maintain the ice packs on the puncture site for about $1 \mathrm{~h}$. Oral antibiotics (Amoxycillin + Clavulanate potassium), analgesics (Paraceta$\mathrm{mol}$ ), and antiedematous (Alphintern) drugs were prescribed for all patients for 1 week duration post procedure. Complications were assessed intraoperatively and postoperatively by the clinical signs and symptoms. Compressive symptoms, cosmetic problem, US examination of the thyroid nodule and thyroid profile were all evaluated on follow-up at 1, 3, and 6 months. The VRR was assessed by US imaging and was calculated by the following equation: volume reduction ratio $(\%)=$ (initial volume $(\mathrm{ml})$ - final volume $(\mathrm{ml})) \times 100) /$ initial volume. Additional ablation (second session) was performed for the following reasons: (1) other lobe nodule to avoid doing bilateral nodules in the same session to decrease the possibility of tracheal compression by postoperative edema, (2) large solid part of the nodule more than 50cc, (3) unsatisfactory response on 1 or 3 months' follow-up, and (4) some nodules with retrosternal extension.

\section{Results}

\section{Baseline characteristics}

The baseline characteristics and clinical data of the patients are summarized in Table 1 and baseline data of the nodules in Table 2. Four patients needed a second session; in two of the patients, the second session was done for the same nodule due to large size of the nodule with retrosternal extension in one of them, and in the other two patients, the second session was done for the other lobe nodule. No patient was lost to follow-up in this study.

\section{Volume of the thyroid nodules}

The median of the volume of the nodules was decreased significantly at 1,3 , and 6 months; it was 5.5 (IQR 3.2-12) at 1 month, 3.3 (IQR 1.9-6.8) at 3 months, and 2.2 (IQR 1.2-3.5) at 6 months compared to 15 (IQR $8.5-39.5$ ) pretreatment $P$ value $<0.001$. The volume reduction ratio (\%) was statistically significant. The mean VRR \pm SD was $58.41 \pm 15.27$ at 1 month, $73.26 \pm 11.22$ at 3 months, and $82.54 \pm 12.49$ at 6 months (Figs. 3 and 4).

Table 4 The correlation between the texture of the thyroid nodule by US and the power of RF ablation

\begin{tabular}{|c|c|c|c|c|c|c|}
\hline \multirow{3}{*}{$\begin{array}{l}\text { RF } \\
\text { ablation } \\
\text { power (W) }\end{array}$} & \multicolumn{3}{|l|}{ U/S picture } & \multirow{3}{*}{$\begin{array}{l}\text { Test } \\
\text { value }\end{array}$} & \multirow{3}{*}{$\begin{array}{l}P \\
\text { value }\end{array}$} & \multirow[t]{3}{*}{ Sig. } \\
\hline & Solid & Complex & Cystic & & & \\
\hline & No. $=27$ & No. $=16$ & No. $=2$ & & & \\
\hline Mean \pm SD & $71.14 \pm 17.32$ & $88.13 \pm 5.44$ & $100.00 \pm 0.00$ & 9.796 & 0.000 & $\mathrm{HS}$ \\
\hline Range & 50-100 & $80-100$ & $100-100$ & & & \\
\hline
\end{tabular}




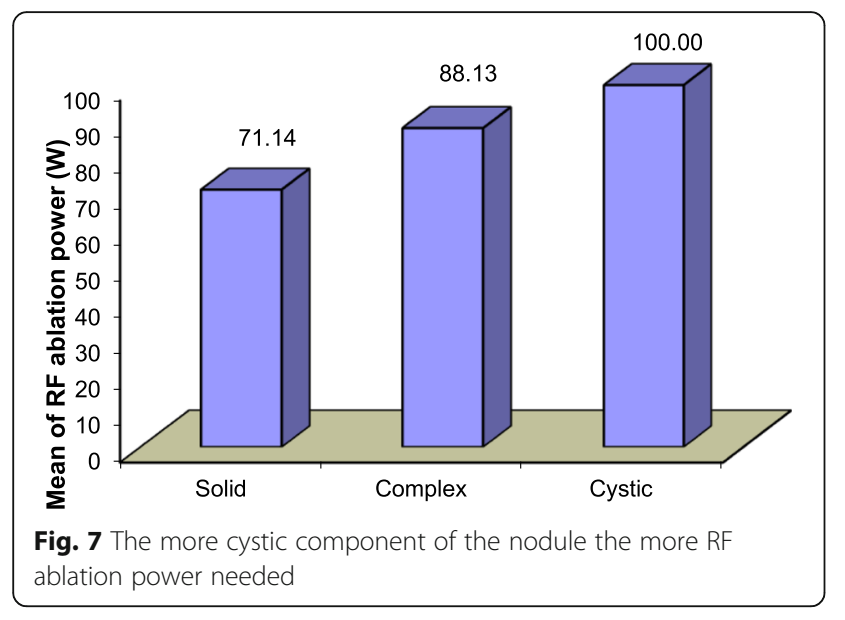

\section{Symptoms evaluation}

The median of the compressive symptoms scoring was significantly decreased; it was 4 (IQR $3-5)$ at 1 month, 2 (IQR $1-3$ ) at 3 months, and 0 (IQR $0-1$ ) at 6 months compared to 8 (IQR 6-9) before RF ablation, $P$ value $<0.001$. The median of the cosmetic problem scoring was 2 (IQR $1.5-2$ ) at 1 month, 1 (IQR $1-2$ ) at 3 months, and 1 (IQR $1-1$ ) at 6 months compared to 4 (IQR 3-4) before treatment $P$ value < 0.001 (Figs. 5 and 6).

\section{Thyroid hormone level evaluation}

The 38 euthyroid patients remained euthyroid at 1, 3, and 6 months follow-up. The two hyperthyroid patients reverted back to euthyroid state after 1 month and remained euthyroid on 3 and 6 months' follow-up. The follow-up of the thyroid nodules' volume, patients' symptoms, and the thyroid hormone level is summarized in Table 3.

\section{The correlation between US picture of the thyroid nodules and the power of RF ablation}

In this study, there was a significant relation between the texture of the thyroid nodule by US and the power of the RF ablation used to achieve the appropriate volume reduction. The mean power used was 71.14 \pm 17.32SD for the solid nodules, $88.13 \pm 5.44 \mathrm{SD}$ for the complex nodules, and 100.00 $\pm 0.00 \mathrm{SD}$ for the cystic nodules. Data are summarized in Table 4 and demonstrated in Fig. 7.

The relation between the composition the thyroid nodule and the volume reduction ratio

During follow-up, there was no significant relation between the composition of the thyroid nodules by US and the VRR. The mean volume reduction ratio of the nodules after 1 month was $59.50 \pm 13.47 \mathrm{SD}$ for the solid nodules, $55.21 \pm 17.26 \mathrm{SD}$ for the complex nodules, and $70.30 \pm 22.28 \mathrm{SD}$ for the cystic nodules. After 3 months, it was $70.39 \pm 11.71$ SD for the solid nodules, 76.14 \pm 9.32SD for the complex nodules, and $90.30 \pm 0.00 \mathrm{SD}$ for the cystic nodules. After 6 months, it was $81.02 \pm 10.81$ SD for the solid nodules, $84.00 \pm 14.82 \mathrm{SD}$ for the complex nodules, and $92.42 \pm 0.00 \mathrm{SD}$ for the cystic nodules. $P$ value was $>$ 0.05. The data are summarized in Table 5 and demonstrated in Fig. 8.

\section{Complications and safety}

Major and minor complications were those defined by the Society of Interventional Radiology (SIR) [22, 23]. A major complication was defined as one that, if left untreated, might threaten the patient's life, lead to substantial morbidity or disability, or result in a lengthened hospital stay. All other complications were considered minor. Thirty-seven 37 (92.5\%) out of 40 patients did not develop any complications during the study. One of the 40 patients (2.5\%) developed a major complication, grade $C$ "according to the SIR complication classification" it was voice changes immediately after the procedure; the patient had a thyroid nodule located close to the recurrent laryngeal nerve and the nerve compressed by the edema and hydro dissection, and we discharged the patient to

Table 5 The relation between the composition the thyroid nodule and the volume reduction ratio

\begin{tabular}{|c|c|c|c|c|c|c|c|}
\hline & & \multicolumn{3}{|l|}{ U/S picture } & \multirow{3}{*}{$\begin{array}{l}\text { Test } \\
\text { value }\end{array}$} & \multirow{3}{*}{$\begin{array}{l}\mathrm{P} \text { - } \\
\text { value }\end{array}$} & \multirow[t]{3}{*}{ Sig. } \\
\hline & & Solid & Complex & Cystic & & & \\
\hline & & No. $=27$ & No. $=16$ & No. $=2$ & & & \\
\hline \multirow[t]{2}{*}{ Volume reduction ratio after 1 month } & Mean \pm SD & $59.50 \pm 13.47$ & $55.21 \pm 17.26$ & $70.30 \pm 22.28$ & $1.022^{\mathrm{a}}$ & 0.369 & NS \\
\hline & Range & $30-96.23$ & $29.52-89.33$ & $54.55-86.06$ & & & \\
\hline \multirow[t]{2}{*}{ Volume reduction ratio after 3 months } & Mean \pm SD & $70.39 \pm 11.71$ & $76.14 \pm 9.32$ & $90.30 \pm 0.00$ & $2.600^{\mathrm{a}}$ & 0.088 & NS \\
\hline & Range & $40-87.33$ & $60-94.14$ & $90.3-90.3$ & & & \\
\hline \multirow[t]{2}{*}{ Volume reduction ratio after 6 months } & Mean \pm SD & $81.02 \pm 10.81$ & $84.00 \pm 14.82$ & $92.42 \pm 0.00$ & $0.572^{\mathrm{a}}$ & 0.569 & NS \\
\hline & Range & $57.45-92.13$ & $36-98.28$ & $92.42-92.42$ & & & \\
\hline
\end{tabular}

$P$ value $>0.05$, non-significant; $P$ value $<0.05$, significant; $P$ value $<0.01$, highly significant 


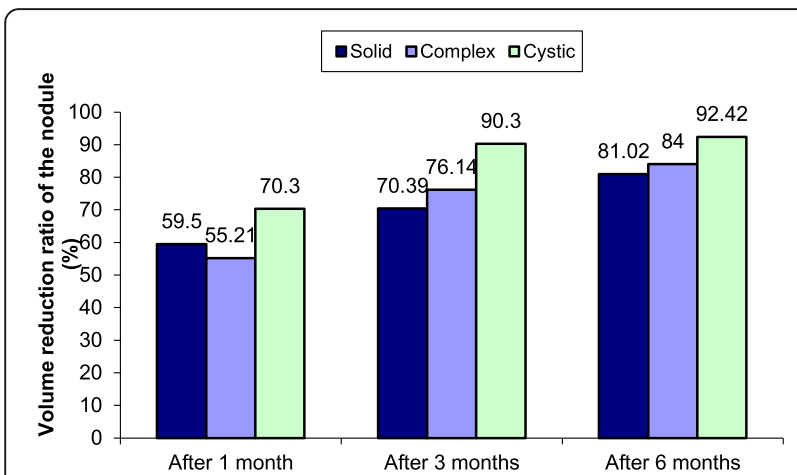

Fig. 8 The relation between the initial US composition of the thyroid nodules and the volume reduction ratio after RF ablation

the recovery room after the procedure and put her under observation for $6 \mathrm{~h}$. The voice changes were transient and fully recovered after about $4 \mathrm{~h}$ when the edema is partially absorbed by the tissues. Two patients (5\%) developed minor complications. One of them $(2.5 \%)$ developed first degree burn during the ablation, grade $\mathrm{B}$ 'according to the SIR complication classification', the patient had a thyroid nodule at the isthmus very superficially and the hydro dissection could not prevent the skin burn to happen. It recovered completely without scar formation after about 1 month duration with topical treatment. The other patient $(2.5 \%)$ developed small hematoma, grade A 'according to the SIR complication classification' due to minor touch of the carotid artery by the tip of the electrode during ablation, the patient had a nodule adjacent to the common carotid artery and the hydro dissection was not enough to separate the nodule from the carotid artery, we removed the electrode and compressed the neck for $10 \mathrm{~min}$, the hematoma subsided, and it resolved completely at the same day after about $3 \mathrm{~h}$. No sustained complication happened. No life-threating complications. Summary of complications and its fate are demonstrated in Table 6 and Figs. 9 and 10.

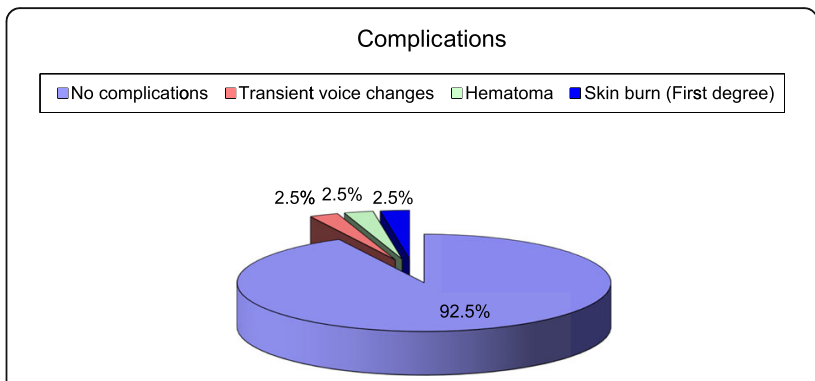

Fig. 9 Summary of complications

\section{Discussion}

The present study shows that RF ablation resulted in a significant reduction in the volume of the benign thyroid nodules (Fig. 11). The volume reduction ratio (\%) was $82.54 \pm 12.49 \mathrm{SD}$ after 6 months. In other studies, the maximum benefit was reported to be 69 to $90 \%$ and was found at 6 to 9 months $[15,22,24,25]$. RF ablation improved the compressive and/or cosmetic problems (Fig. 12). It did not affect the function of the normal thyroid gland. There was strong relation between the US texture of the thyroid nodule and the RF power used during the ablation to achieve the appropriate nodule volume reduction. Cystic nodules usually need a higher RF ablation power in comparison to the solid nodules; this was not mentioned before in any literature. There was no significant relation between the composition of the nodule and the volume reduction ratio of the thyroid nodules at 1,3 , and 6 months. Jeong et al. [16] reported that at 1 and 3 months' follow-up, cystic nodules decreased in size more than the other types $(P=0.000$ and 0.007 , respectively) but there was no significant difference between the types of the nodules at 6 months' follow-up $(P=0.621)$. The nodules which needed a second session to achieve appropriate volume reduction are the larger nodules "its solid component more than $50 \mathrm{ml}$ in volume", thyroid nodules at both thyroid lobes as well as thyroid nodules with retrosternal extension. Several previous studies [26-28] reported that one

Table 6 Demonstration of complications happened in the 40 patients, no sustained or life-threating complications

\begin{tabular}{|c|c|c|c|c|}
\hline & 1 Major (2.5\%) & & 2 Minor (5\%) & \\
\hline \multirow[t]{5}{*}{ Overall complications3 (7.5\%) } & Transient voice changes (fully recovered) & $1(2.5 \%)$ & Hematoma & $1(2.5 \%)$ \\
\hline & Nodule rupture & $0(0.0 \%)$ & Skin burn (first degree) & $1(2.5 \%)$ \\
\hline & Nodule rupture with abscess formation & $0(0.0 \%)$ & Vomiting & $0(0.0 \%)$ \\
\hline & Hypothyroidism & $0(0.0 \%)$ & - & - \\
\hline & Brachial plexus injury & 0 (0.0\%) & - & - \\
\hline
\end{tabular}




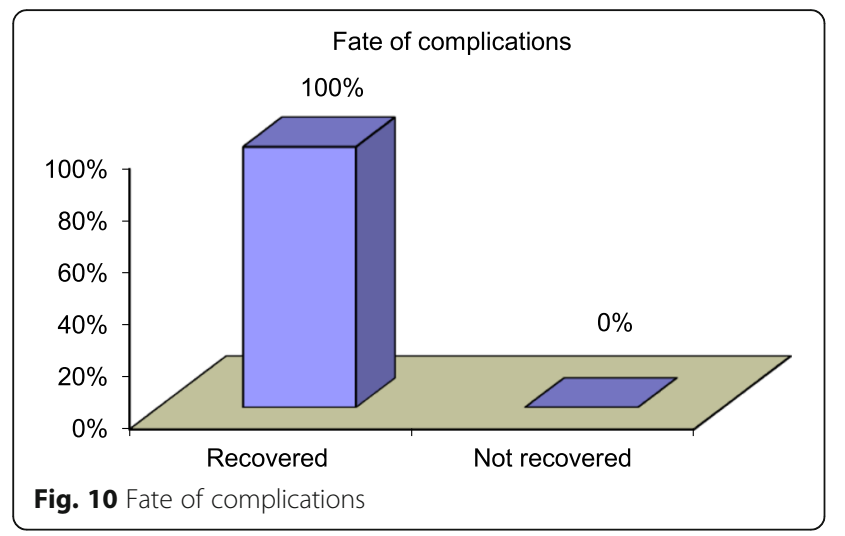

treatment session was sufficient for treatment of thyroid nodules, because the primary purpose of thyroid nodule ablation was the resolution of cosmetic problems and nodule-related symptoms rather than complete ablation. However, marginal regrowth of an incompletely treated nodule may be a major cause of recurrent symptoms during follow-up. Large nodules require multiple treatment sessions, because a single session cannot result in complete ablation. RF ablation is effective in the treatment of recurrent benign thyroid nodules after surgical treatment. No patients required additional surgery or other treatment during the follow-up period because of recurrence or incompletely resolved clinical problems. No sustained or life-threatening complications happened. Although surgery is a curative treatment for the benign thyroid nodules, yet permanent hypothyroidism is inevitable after total gland resection. In addition, unilateral lobectomy can cause subclinical or clinical hypothyroidism [29]. The most common complications of thyroid surgery are vocal cord palsy, postoperative hemorrhage, and hypothyroidism [30]. More recent studies have reported an incidence of permanent, recurrent laryngeal nerve palsy of $0.3-1.7 \%$ and of permanent hypoparathyroidism of $0.7-$ $3 \%$ after total thyroidectomy for benign thyroid nodules [31]. Surgery also has other drawbacks, including general anesthesia and cosmetic scar formation. RF ablation preserves normal thyroid gland function and minimizes the complications compared to surgery. Several studies have reported that RF ablation is an effective and safe alternative to surgery for treating benign thyroid nodules $[16,17]$. Lim et al. [21] reported that RF was effective in shrinking benign thyroid nodules and in controlling nodule-related problems over a 4-year follow-up for 111 patients with no life-threatening complications. Jeong

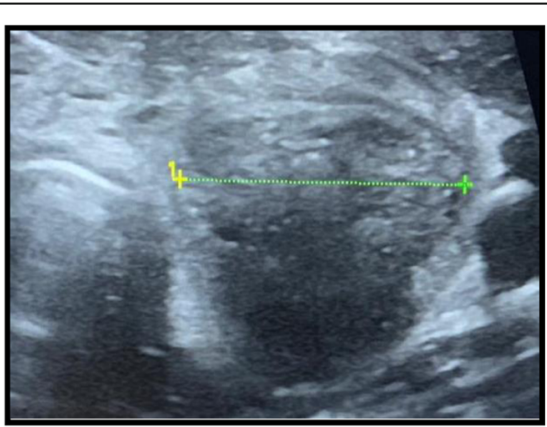

(a)

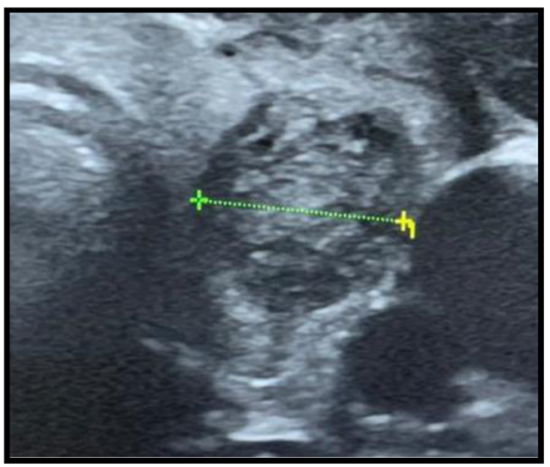

(c)

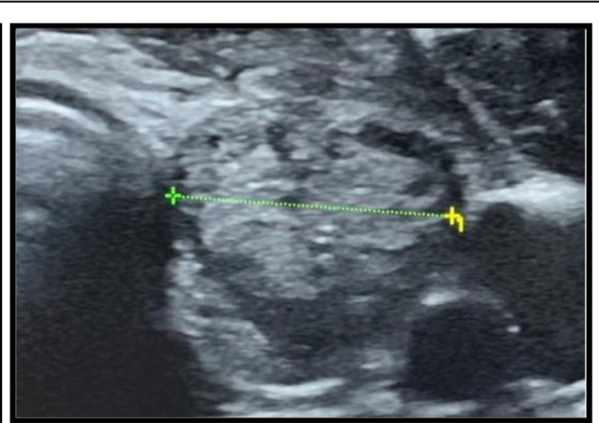

(b)

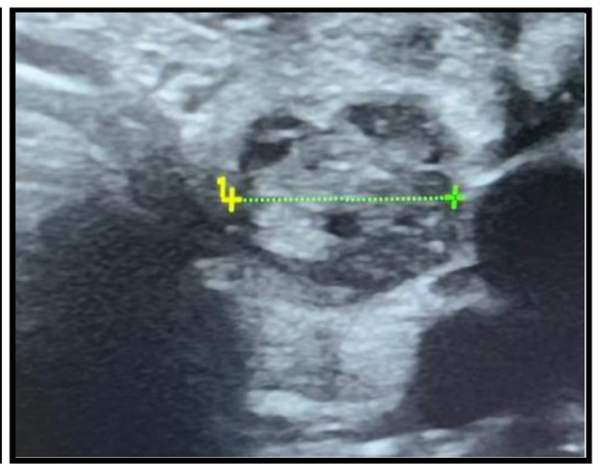

(d)

Fig. 11 A 36-year-old woman presented with solitary benign thyroid nodule. a Transverse US imaging performed before RF ablation shows a left solid nodule. $\mathbf{b}$ Transverse US image obtained after 1-month follow-up shows decreasing in the size of the nodule. c Volume reduction of the treated nodules on 3-month follow-up. d Marked volume reduction of the left nodule is noted on US image obtained 6 months after RF ablation 


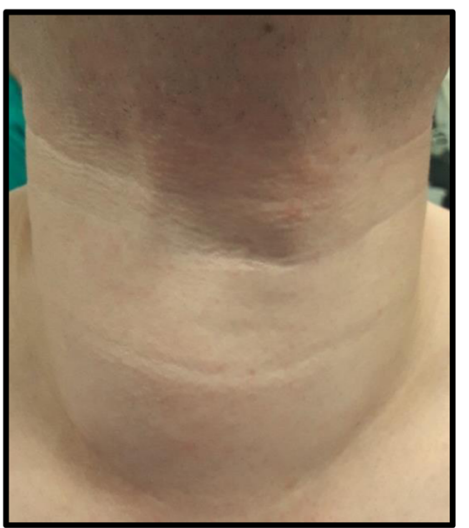

(a)

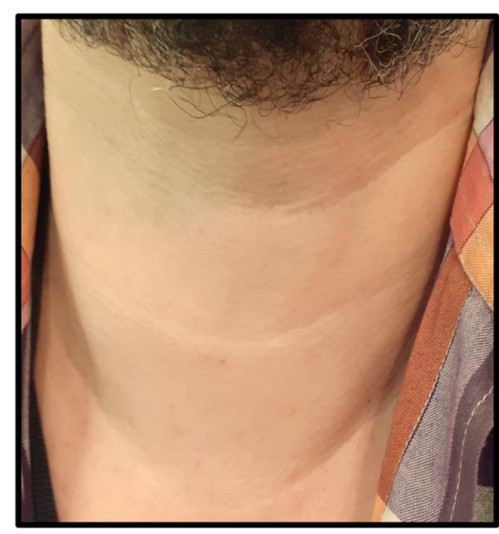

(b)

Fig. 12 A 42-year-old male patient had complained of neck bulging due to benign thyroid nodule. a Before RF ablation, he had severe neck bulging. b After RF ablation, neck bulging improved gradually during the follow-up period ( 6 months after RF ablation)

et al. [16] demonstrated that RF ablation was safe and effective in decreasing the volume of the thyroid nodules during follow-up of 236 patients. Hamidi et al. [3] reported that RF ablation could be an alternative to surgery in the management of both toxic and non-toxic benign thyroid nodules through a study done on 14 patients with benign thyroid nodules. Baek et al. [32] reported that the complications happened from RF ablation for 1459 patient with 1543 thyroid nodules were 48 complications (3.3\%); all complications were recovered with no sustained complications.

\section{Conclusion}

US-guided RF ablation is an alternative non-surgical minimally invasive modality in the treatment of the benign thyroid nodules. It is an effective method in reducing the size of the benign thyroid nodules and in controlling nodule-related compressive symptoms and cosmetic problems. RF ablation is a safe procedure and can minimize the complications could happen from surgery.

\section{Abbreviations}

RFA: Radiofrequency ablation; US: Ultrasound; FNAB: Fine needle aspiration biopsy; AFTN: Autonomously functioning thyroid nodule; TSH: Thyroidstimulating hormone; T3: Triiodothyronine; T4: Thyroxine; VRR: Volume reduction ratio; IQR: Interquartile range

\section{Acknowledgements}

Not applicable.

\section{Authors' contributions}

MA: collected the patients' data, evaluated the patients' clinical symptoms and ultrasound picture during the follow-up, and assisted in the procedure's technique. AA: revised the data and analyzed it. RB: clinical examination of the patients before the procedure. YA: interpreted the data collected. $\mathrm{OH}$ : performed the radiofrequency ablation for the patients to treat the benign thyroid nodules. All authors read and approved the final manuscript.
Funding

This study was not supported by any funding.

\section{Availability of data and materials}

The data and material used in this study is available.

\section{Ethics approval and consent to participate}

The study is approved by Ain Shams University ethical and scientific committee "The committee's reference number is not available". A written informed consent is obtained from all patients before the procedure.

\section{Consent for publication}

Consent for publication was obtained for every individual person's data included in the study.

\section{Competing interests}

There are no competing interests in this study.

\section{Author details}

'Radiodiagnosis Department, Ain Shams University Hospitals, Cairo, Egypt. ${ }^{2}$ Internal Medicine and Endocrinology Department, Ain Shams University Hospitals, Cairo, Egypt.

Received: 8 January 2021 Accepted: 3 February 2021

Published online: 18 February 2021

\section{References}

1. Garberoglio R, Aliberti C, Appetecchia M et al (2015) Radiofrequency ablation for thyroid nodules: which indications? The first Italian opinion statement. J Ultrasound 18:423-430

2. Fuller CW, Nguyen SA, Lohia S et al (2014) Radiofrequency ablation for treatment of benign thyroid nodules systematic review. Laryngoscope 124: $346-353$

3. Hamidi O, Callstrom MR, Lee RA et al (2018) Outcomes of radiofrequency ablation therapy for large benign thyroid nodules: a Mayo Clinic case series. Mayo Clinic Proceedings. https://doi.org/10.1016/j.mayocp.2017.12.011

4. Hong MJ, Baek JH, Jun Y et al (2015) Radiofrequency ablation is a thyroid function preserving treatment for patients with bilateral benign thyroid nodules. J Vasc Interv Radiol 26:55-61

5. Kim JH, Baek JH, Lim HK et al (2019) Summary of the 2017 thyroid radiofrequency ablation guideline and comparison with the 2012 guideline. Ultrasonography 38(2):125-134

6. Lee MT, Wang CW (2013) Radiofrequency ablation in nodular thyroid diseases. J Med Ultrasound 21:62-70 
7. Oertel YC, Miyahara-Felipe L, Mendoza MG et al (2007) Value of repeated fine needle aspirations of the thyroid: an analysis of over ten thousand FNAs. Thyroid 17(11):1061-1066

8. Kwak JY, Koo H, Youk JH et al (2010) Value of US correlation of a thyroid nodule with initially benign cytologic results. Radiology 254(1):292-300

9. Moon WJ, Baek JH, Jung SL et al (2011) Ultrasonography and the ultrasound -based management of the thyroid nodules: consensus statement and recommendations. Korean J Radiol 12(1):1-14

10. Baloch Z, Carayon P, Conte-Devolx B et al (2003) Laboratory medicine practice guidelines. Laboratory support for the diagnosis and monitoring of thyroid disease. Thyroid 13(1):3

11. Ha EJ, Baek JH, Lee JH (2011) The efficacy and complications of radiofrequency ablation of thyroid nodules. Curr Opin Endocrinol Diabetes Obes 18:310-314

12. Na DG, Lee JH, Jung SL et al (2012) Radiofrequency ablation of benign thyroid nodules and recurrent thyroid cancers: consensus statement and recommendations. Korean J Radiol 13:117-125

13. Baek JH, Lee JH, Valcavi $R$ et al (2011) Thermal ablation for benign thyroid nodules: radiofrequency and laser. Korean J Radiol 12:525-540

14. Lee JH, Kim YS, Lee D et al (2010) Radiofrequency ablation (RFA) of benign thyroid nodules in patients with incompletely resolved clinical problems after ethanol ablation (EA). World J Surg 34(7):1488-1493

15. Baek JH, Moon WJ, Kim YS et al (2009) Radiofrequency ablation for the treatment of autonomously functioning thyroid nodules. World J Surg. 33(9):1971-1977

16. Jeong WK, Baek JH, Rhim H et al (2008) Radiofrequency ablation of benign thyroid nodules: safety and imaging follow-up in 236 patients. Eur Radiol 18:1244-1250

17. Baek JH, Kim YS, Lee D et al (2010) Benign predominantly solid thyroid nodules: prospective study of efficacy of sonographically guided radiofrequency ablation versus control condition. AJR Am J Roentgenol 194: 1137-1142

18. Shin JH, Baek JH, Ha EJ et al (2012) Radiofrequency ablation of thyroid nodules: basic principles and clinical application. Int J Endocrinol 2012: 919650. https://doi.org/10.1155/2012/919650. Epub 2012 Oct 22. PMID: 23133449; PMCID: PMC3485526

19. Wong KP, Hin Lang BH (2013) Use of radiofrequency ablation in benign thyroid nodules: a literature review and updates. Int J Endocrinol 428363:7

20. Kim C, Lee JH, Choi YJ et al (2017) Complications encountered in ultrasonography-guided radiofrequency ablation of benign thyroid nodules and recurrent thyroid cancers. Eur Radiol. 27(8):3128-3137

21. Lim HK, Lee JH, Ha EJ et al (2013) Radiofrequency ablation of benign nonfunctioning thyroid nodules: 4-year follow-up results for 111 patients. Eur Radiol 23(4):1044-1049

22. Burke DR, Lewis CA, Cardella JF et al (2003) Quality improvement guidelines for percutaneous transhepatic cholangiography and biliary drainage. J Vasc Interv Radiol 14(9 Pt 2):S243-S246

23. Lewis CA, Allen TE, Burke DR et al (1997) Quality improvement guidelines for central venous access. The Standards of Practice Committee of the Society of Cardiovascular \& Interventional Radiology. J Vasc Interv Radiol 8(3):475-479

24. Cesareo R, Pasqualini V, Simeoni $C$ et al (2015) Prospective study of effectiveness of ultrasound-guided radiofrequency ablation versus control group in patients affected by benign thyroid nodules. J Clin Endocrinol Metab. 100(2):460-466

25. Faggiano A, Ramundo V, Assanti AP et al (2012) Thyroid nodules treated with percutaneous radiofrequency thermal ablation: a comparative study. J Clin Endocrinol Metab 97(12):4439-4445

26. Spiezia S, Vitale G, Di Somma C et al (2003) Ultrasound-guided laser thermal ablation in the treatment of autonomous hyperfunctioning thyroid nodules and compressive nontoxic nodular goiter. Thyroid 13:941-947

27. Deandrea M, Limone P, Basso E et al (2008) US-guided percutaneous radiofrequency thermal ablation for the treatment of solid benign hyperfunctioning or compressive thyroid nodules. Ultrasound Med Biol 34 784-791

28. Kim YS, Rhim H, Tae K et al (2006) Radiofrequency ablation of benign cold thyroid nodules: initial clinical experience. Thyroid 16:361-367

29. Su SY, Grodski S, Serpell JW (2009) Hypothyroidism following hemithyroidectomy: a retrospective review. Ann Surg 250(6):991-994
30. Ozbas S, Kocak S, Aydintug S et al (2005) Comparison of the complications of subtotal, near total and total thyroidectomy in the surgical management of multinodular goitre. Endocrine J 52(2):199-205

31. Bron LP, O'Brien CJ (2004) Total thyroidectomy for clinically benign disease of the thyroid gland. Br J Surg 91:569-574

32. Baek JH, Lee JH, Song JY et al (2012) Complications encountered in the treatment of benign thyroid nodules with US-guided radiofrequency ablation. Radiology 262(1):335 radiology.rsna.org

\section{Publisher's Note}

Springer Nature remains neutral with regard to jurisdictional claims in published maps and institutional affiliations.

\section{Submit your manuscript to a SpringerOpen ${ }^{\circ}$ journal and benefit from:}

- Convenient online submission

- Rigorous peer review

- Open access: articles freely available online

High visibility within the field

- Retaining the copyright to your article

Submit your next manuscript at $\boldsymbol{\nabla}$ springeropen.com 